\title{
Unveiling the consensus: Putting people first in Pakistan's development agenda
}

Government of Pakistan

UNFPA

Population Council

Follow this and additional works at: https://knowledgecommons.popcouncil.org/departments_sbsr-pgy

Part of the Demography, Population, and Ecology Commons, Family, Life Course, and Society Commons, and the International Public Health Commons How does access to this work benefit you? Let us know!

\section{Recommended Citation}

Government of Pakistan, UNFPA, and Population Council. 2015. "Unveiling the consensus: Putting people first in Pakistan's development agenda." Islamabad: Government of Pakistan, UNFPA, and Population Council. 

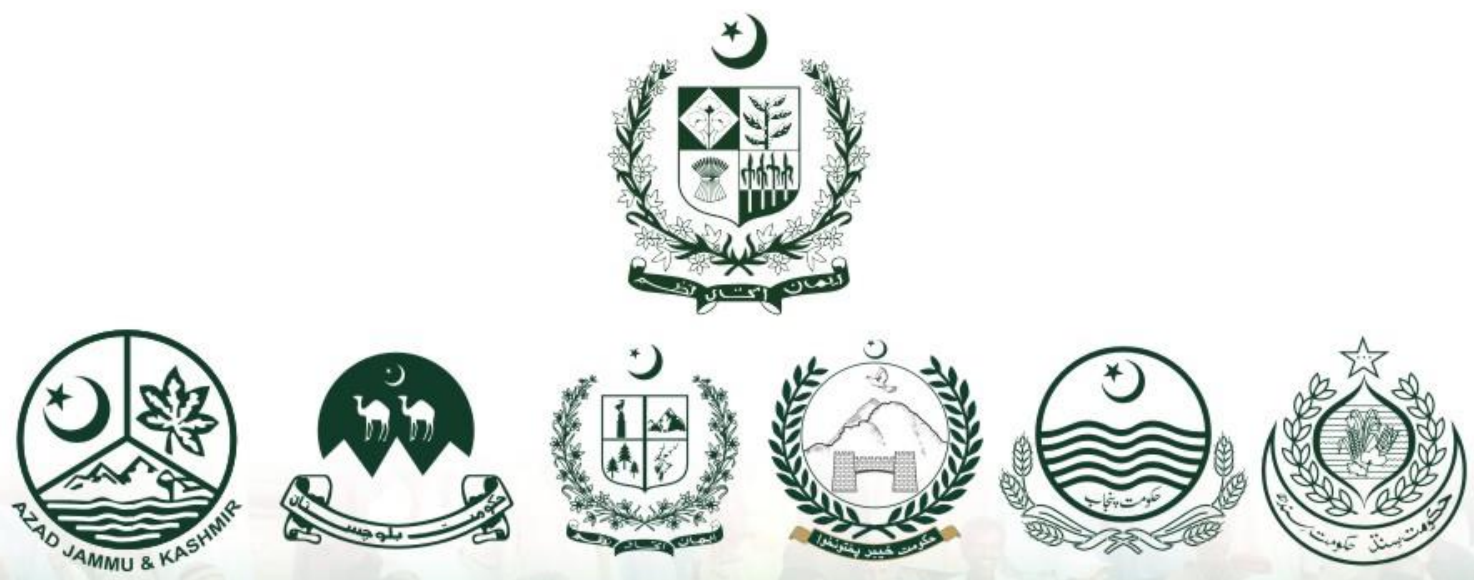

\section{Unvefling the Consensus}

\section{Putting People First in Pakistan's Development Agenda}

\section{Population Summit 2015}

\section{Islamabad, November 5-6}




\title{
Putting People First in Pakistan's Development Agenda
}

\author{
If we want to make this great State of Pakistan happy and prosperous \\ we should wholly and solely concentrate on the well-being of the people, \\ and especially of the masses and the poor.
}

Muhammad Ali Jinnah, August 11, 1947

Pakistan's Constitution promotes the social, economic and cultural rights of citizens

The Constitution of the Islamic Republic of Pakistan reflects the deep concern of the founding fathers to protect and promote the social, economic, and cultural rights of all citizens. The Constitution requires the State to take steps that ensure the full participation of women in all spheres of life; to safeguard the rights and interests of minorities; to secure the well-being of the people by raising their standard of living; to make higher education available and accessible; and to enable the people of different areas to participate fully in all forms of national activities, through education, training, agricultural and industrial development. It calls on the State to protect the bedrock of Pakistani society: marriage, the family, the mother, and the child.

Until recently, attention to these prerogatives of human development has remained $\operatorname{dim}$ against a backdrop of massive economic, political, and security challenges, and meeting the urgent infrastructure needs of a huge and rapidly growing population. But realization is dawning that we have reached the limits of this approach. To reach the next destination in our national journey, we must do as some of our Asian neighbors have done, and turn our biggest burden, human need, into our greatest asset-human capital.

\section{Pakistan 2025 - One Nation, One Vision forges a representative agenda of all provinces}

Following an extensive process of consultation with provincial governments and other stakeholders, in 2014, the Government of Pakistan announced Pakistan 2025 - One Nation, One Vision. This document marks a historic landmark. As a consensus, it represents an important effort to actualize the aims of the $18^{\text {th }}$ Amendment and forge a truly representative agenda that is owned by each province. Further, by declaring "Putting People First" the first of seven key pillars, Vision 2025 integrates the goal of human development with the national strategy for transformational economic growth. Recognizing investment in human and social capital as a prerequisite for all other development, the government has promised a "very significant increase" in resource allocation, and "quantum improvement" in the quality of interventions in the spheres of education, health, population, gender equality and women's empowerment, and youth, among others.

Vision 2025 accurately diagnoses the ways in which demographic trends will shape, and be shaped by, Pakistan's future development. It acknowledges that the rapid growth in population poses serious challenges for making progress against key social indicators, especially food security and access to water in an era of climate change. Moreover, while the young age structure of the population could translate into a demographic dividend, the government is also aware that reaping this dividend requires the creation of more than a million jobs every year.

\section{Population dynamics matter for development}

With proactive policies, including strong family planning programming, population dynamics can be steered to propel, rather than impede, national development. We now know, from international experience as well as our own, that voluntary use of birth spacing methods reduces unintended pregnancies and abortions; lowers child and 
maternal mortality and malnutrition; halts the spread of communicable diseases; and contributes to lower fertility and slower population growth. When men and women are empowered through access to contraceptive information and services, they tend to have the number of children as they can best provide for. Healthier, smaller families are more resilient in coping with environmental and other crises. In these households, women are more likely to work and to enjoy gender equality, and parents are more likely to invest resources in the human capital of their children, both girls and boys. For the country, the higher ratio of the working age to dependents, and greater investment in human capital will make it possible for Pakistan to experience a powerful surge in economic growth through the demographic dividend. Simply put, family planning is key for achieving our national development agenda.

Pakistan is ready to put an accelerated program of family planning at the center of the post-2015 development agenda

To date, an enduring commitment to a sound and adequate population welfare program has eluded
Pakistan, leaving millions of couples who want to wait before having their next child or who consider that they have enough children, without good access to family planning. Until 2010, centralization of health and population policies and the resulting low ownership and weak implementation of family planning programs at the provincial level contributed to this problem.

However, in the wake of devolution, in part through efforts of donors and civil society for awareness building, advocacy, and dialogue, opinion among all major stakeholders is coalescing around the need to address Pakistan's alarming maternal and child health indicators through strong programming, including access to voluntary birth spacing services. As the following pages show, the majority of elected representatives from all provinces and major political parties, and religious scholars of all major schools of thought, have come out to express their unequivocal and enthusiastic support for the right of couples to use contraception for healthy spacing and timing of pregnancies. We have an unprecedented window of opportunity to galvanize progress towards our national vision.

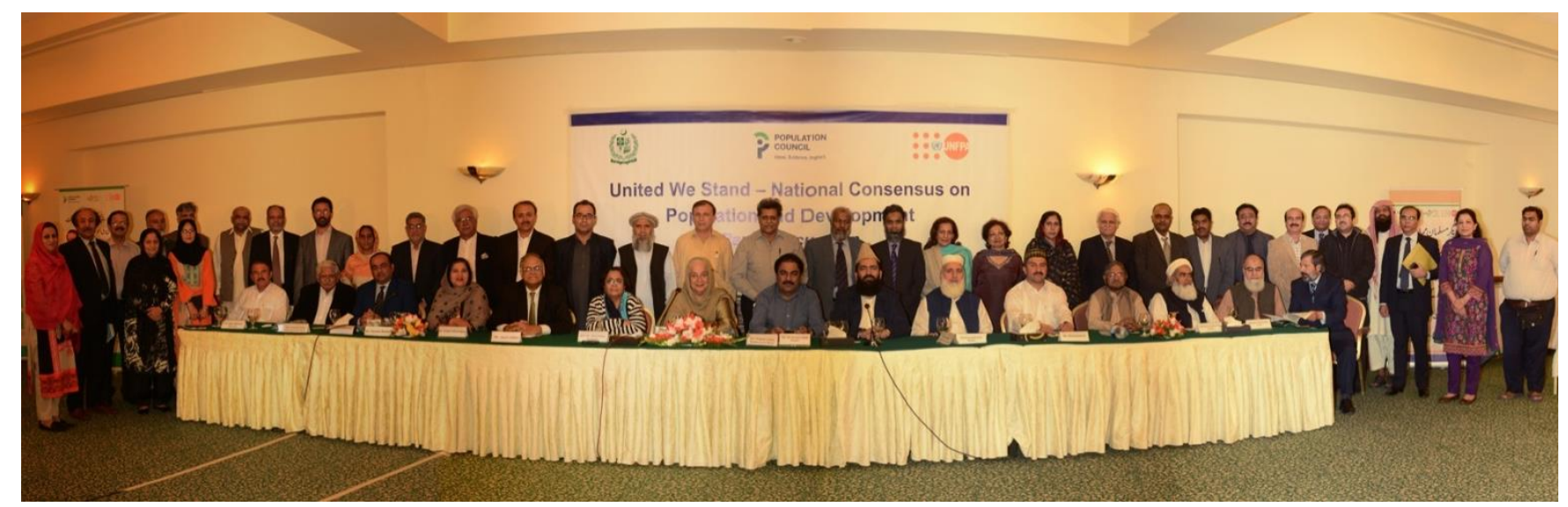

Provincial Health Ministers; officials of the Provincial Health, Population Welfare, and Planning and Development departments; representatives of the Federal Ministry of Health; eminent religious leaders; and representatives of civil society stand united supporting a national consensus on population and development in Bhurban, October 13, 2015. 


\section{The National Consensus}

\section{Religious Scholars and Leaders}

In some parts of Pakistan, misperceptions prevail regarding the permissibility of using contraception to space or limit births in Islam. Several Muslim countries, including neighboring Iran and Bangladesh, have met this ideational challenge head on, by proactively seeking the endorsement of religious leaders and scholars (ulema) for family planning programs. In this manner, they have not only succeeded in increasing public demand for contraception but also provided firmer footing for healthcare providers, government officials, and political representatives to confidently play their roles in promoting family planning.

The past two years have seen Pakistan's most eminent religious leaders and scholars come together to endorse the concept of birth spacing, and the use of contraceptive methods to enable healthy timing and spacing of pregnancies, thereby preventing the tragic loss of maternal and child lives and improving the health and wellbeing of families.

On June 30, 2015, at a meeting organized by the United Nations Population Fund (UNFPA) and the Population Council, honorable ulema and leaders representing all sects, schools of thought, and religious political parties signed a Declaration on the Islamic Perspective on Improving Family Health and Wellbeing.

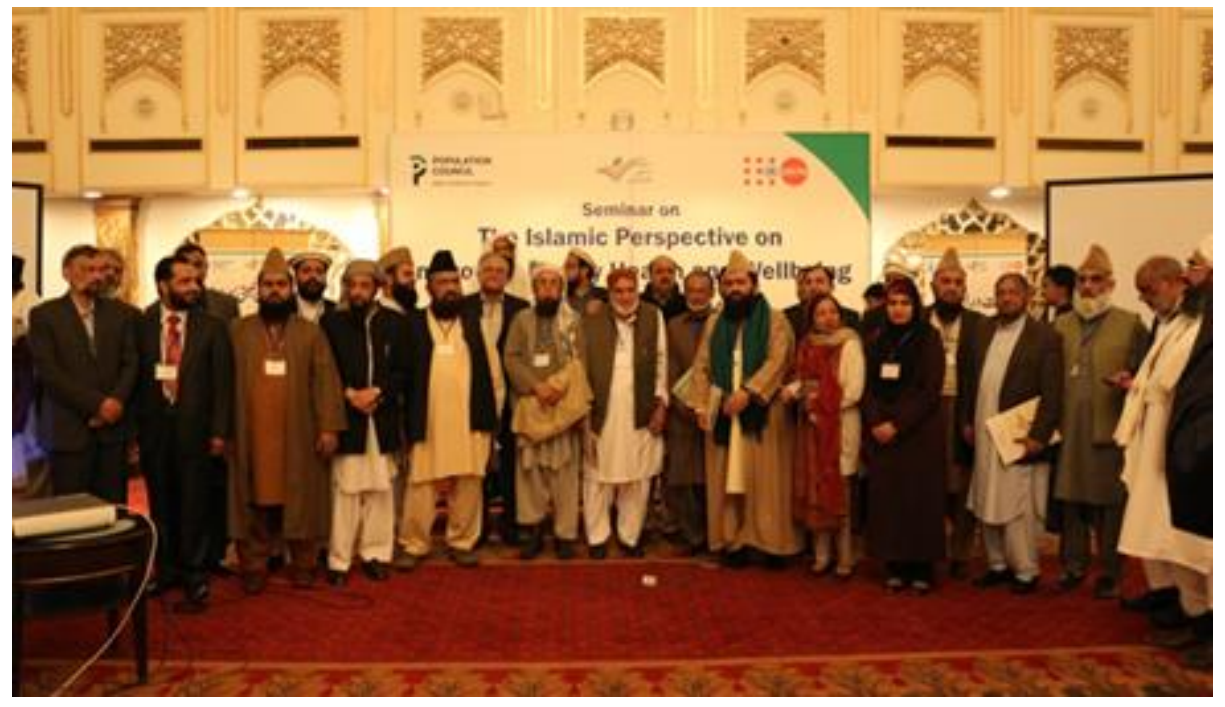

Signing of the Ulema's "Declaration on the Islamic Perspective on Improving Family Health and Wellbeing," in Islamabad on June 30, 2015
"The ulema have decided to play their role - indeed, we have already started to play it. Now what we have decided should be shared with the country.

"We stand by whatever steps are needed, for the Holy

Prophet aلd said, 'The best of you is he who thinks of the best for others.'

"All stakeholders-political representatives and

bureaucrats-are here. Now let us take this effort forwards. We have cooperated in the past, we are cooperating now, and we will continue to cooperate fully in the future...

"I recommend that awareness building and trainings be provided to ulema in each district so we can move forward to address this issue."

Maulana Abdul Khabir Azad, Grand Imam of Badshahi Mosque, Lahore, October 13, 2015, Bhurban 


\title{
Joint Communiqué/Declaration signed on June 30, 2015
}

This document has been produced in both English and Urdu Languages

\section{In the name of Allah the Most beneficent and Merciful Final Communiqué/Declaration}

\section{The Islamic Perspective on Improving Family Health and Wellbeing}

\author{
Islamabad, June 30, 2015
}

We, the undersigned (Ulema-e-kiram/Muslim religious Leaders and heads of religious institutions), met at Islamabad on June 30, 2015, to discuss and build upon the consensus reached at the meeting arranged by the Population Council on December 29,2014 and to strategize the role the religious leaders can play to promote family health and wellbeing.

\section{Preamble:}

- The Ulema-e-kiram and Mashaikh-e-uzzam unequivocally affirm that Islam declares the preservation and maintenance of human life as an unalienable right of all individuals and families and supports, all measures/means/approaches (that are in conformity to the Islamic teachings) for ensuring the attainment of this basic right.

- We acknowledge that the family is the basic pivot of an Islamic society and that the Holy Quran clearly lays down the foundation of a harmonious family life basing it on love and mercy (Mowada and Rahma) with no hardships or undue burdens placed on any member of the family that can jeopardise the wellbeing of the family. Accordingly repeated unplanned pregnancies are an unwarranted burden for the family as they can lead to adverse maternal and child health outcomes.

- We agree that the death of 14,000 women, every year in Pakistan, due to pregnancy related causes is a grave tragedy and should be avoided, and proper care and attention needs to be given to the upbringing and education of girls.

\section{Endorsement:}

- Based on the injunctions of the Holy Quran and sayings of the Holy Prophet we fully endorse the concept of birth spacing.

- We endorse the use of all methods that can help families to better plan the timing and spacing of their pregnancies to prevent maternal deaths and improve the health and wellbeing of families.

- We unequivocally offer our help and support in promoting the provision of birth spacing services (both ongoing and in the future that are in conformity to the Sharia), thereby, achieving the ultimate goal of creating a healthy, prosperous and welfare oriented society. 


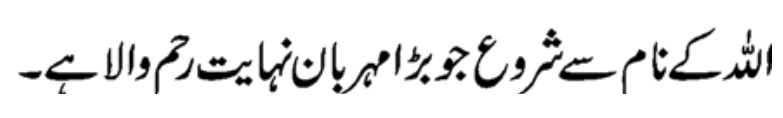

"خ

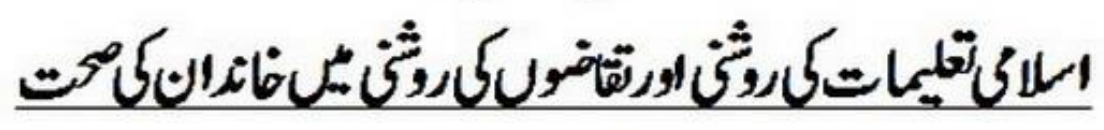

2015،30

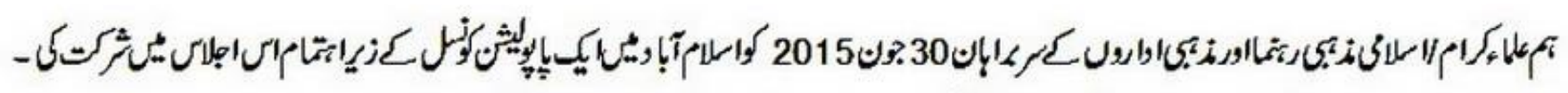

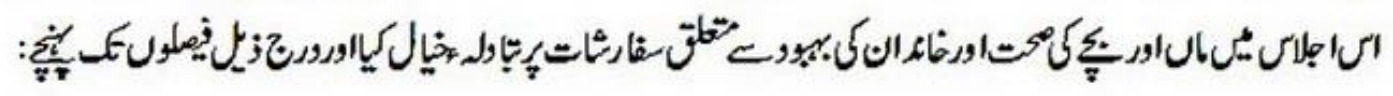

و

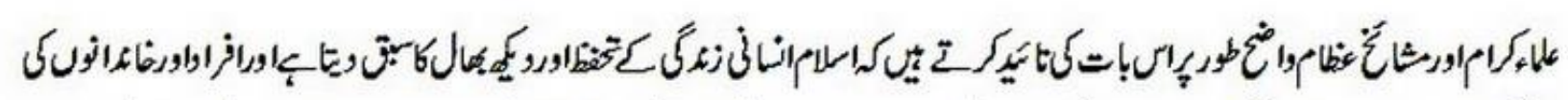
is

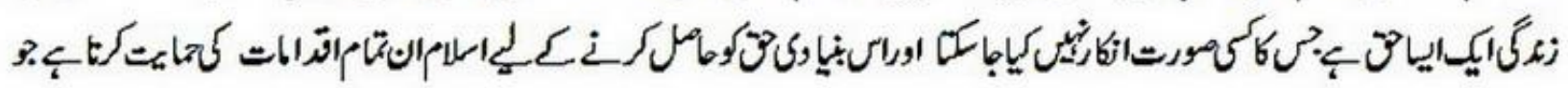

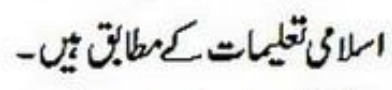

的

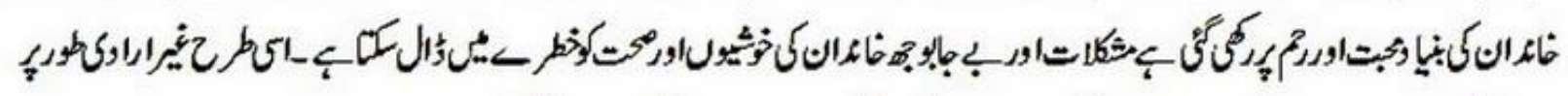

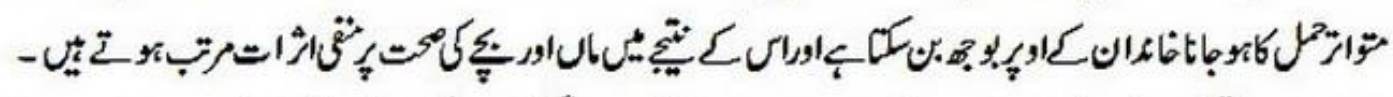

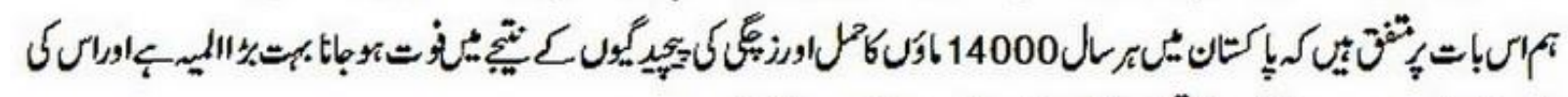

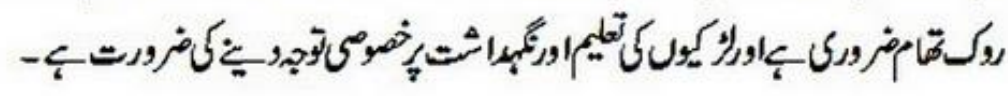

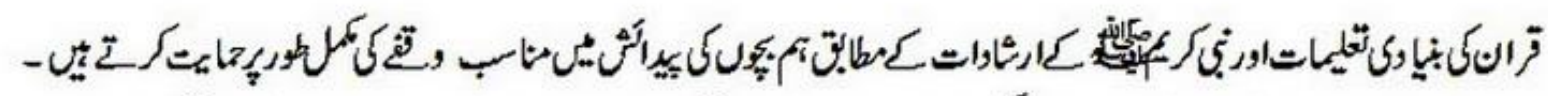

$\dot{\overrightarrow{4}}$

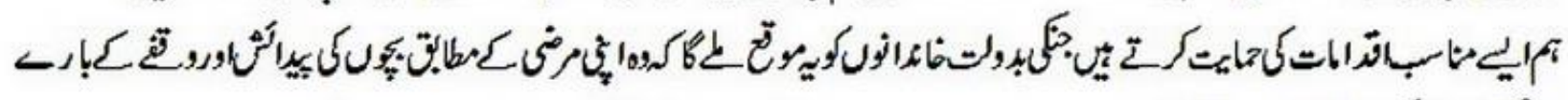

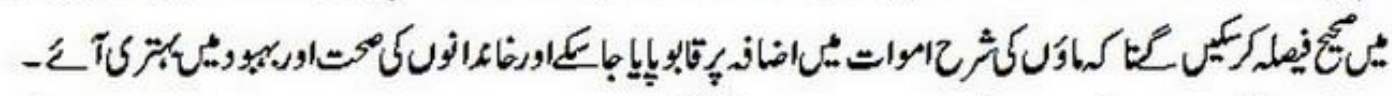

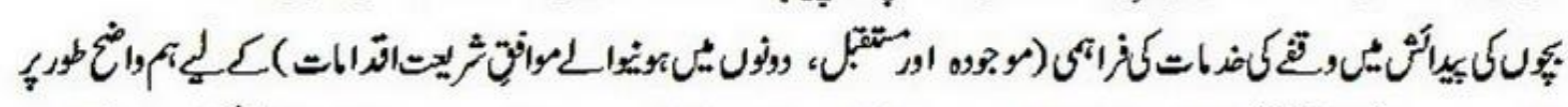

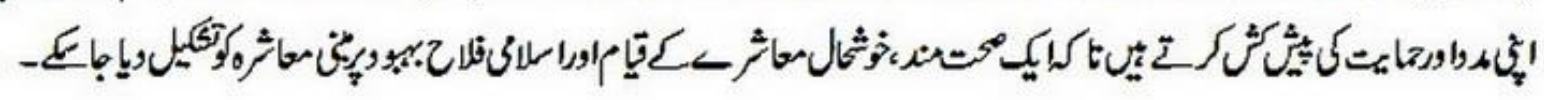


Commitment By:

\section{Name/Signature}

Maulana Abdul Khahir A7ad

مولانبعبانجيمأزار

Maulana Abdullah Khilji

مولاناعبرالذ.

Maulana Anwar UI Haq Haqani

مولا

Mufti Abdul Moeed Asad

$$
\begin{aligned}
& \text { ثفت عبراكمير اس }
\end{aligned}
$$

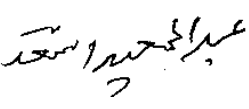

Hafiz Masood Qasim Qasimi مافظمستورقاسم قانئ

Maulana Wali Muhammad Turabi مولاناولقمرتخ

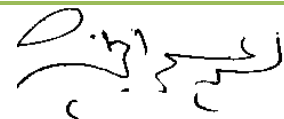

m

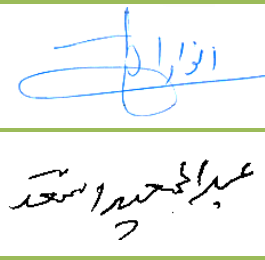

$\xi_{0}=0,2,0$

Sowt

Prof. Dr. Ghulam Ahmed Khan

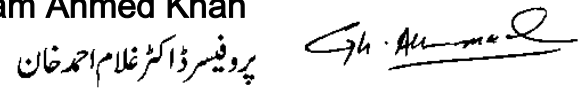

Nureed Fatima<smiles>CCC[As]1CCC1</smiles>

Allama Hafiz Kazim Raza Naqvi علا مسافظكاظم رضانقوى

Ghazanfar Khan Niazi

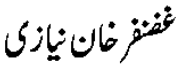

Allama Sajjad Hussain Naqvi

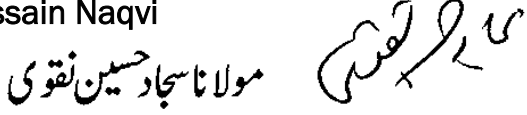

Mufti Ahmed Bakhsh Taugeerwi

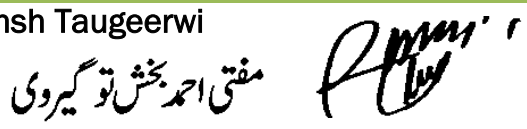

Muhammad Naeem Muneer Farooqi

$$
\text { Nacump }
$$

Prof. Maulana Kaleem Ullah Zia

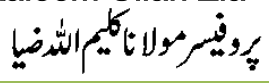

Maulana Prof. Javed Ahmed

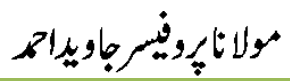

Qari Muhammad Bilal Chishti

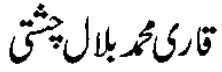

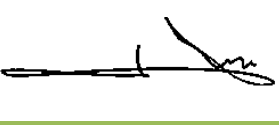

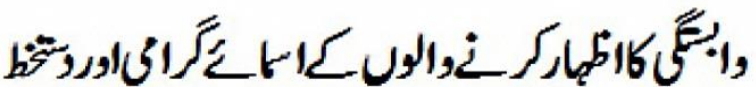

\section{Name/Signature}

Qari Rooh Allah Madni

$$
\text { قاركروحالدّن }
$$

Dr Noor Ahmed Shahtaaz

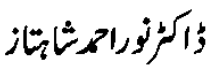

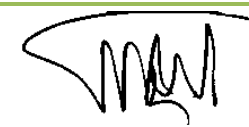

$0-8$

Maulana Hamid UI Haq Haqani مولا ناماراكت تمان

Hafiz Zubair Ahmed Zaheer

$$
\text { مانظزيرامثرمير }
$$

Maulana Muhammad Khan Laghari

$$
\text { S-is } 0,7
$$

Prof. Abdul Ghafoor Najam

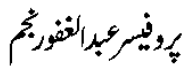

$1+$

Dr. Sakeena Mahdwi

$$
\text { كوبs }
$$

Dr. Syed Muhammad Najfi

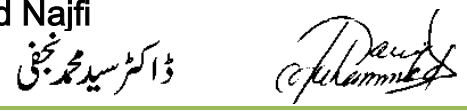

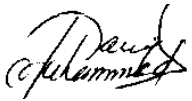

Dr. Tahir Hameed Tanoli

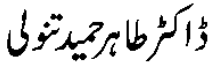

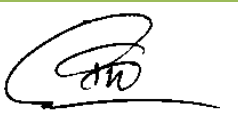

Prof. Dr. Zafar Ullah Jaan

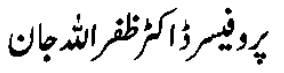

Maulana Abdul Zahir Farooqi

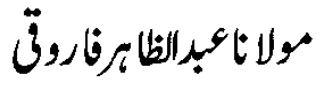

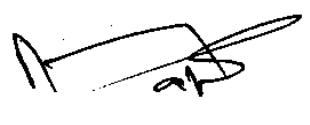

Tahir Mahmood Ahmed Qadri

$$
\text { طابكمورامثقاورى }
$$

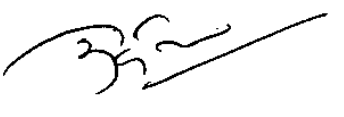

Maulana Hamid Raza

مولاناbا

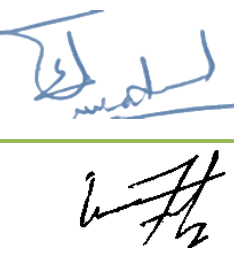

Muhammad Sohail Mufti

$$
\text { محم بهمي منتخ }
$$

Dr. Hafiz Muhammad Saijad

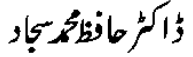

Sufi Nisaar Ahmed Siddiqui

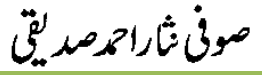




\section{Political Leaders}

Over the past two years, a broad-based multi- party consensus on dealing with the population issue confronting Pakistan has emerged. Prior to the national elections in 2013, briefings for the leadership of Pakistan's major political parties highlighting the urgent need for population stabilization, resulted in all major political parties including this issue in their manifestos. Post elections, town hall style meetings with elected representatives of the parties that had formed governments in the provinces provided an opportunity for people to ask their representatives how they planned to implement the promises in their manifestoes, including the population issue.

After the 18th Amendment, responsibility for population welfare issues was transferred from the federal government to the provincial level. It was necessary to orient law makers and key provincial policymakers to the strong linkages between population growth and provincial development.

Several rounds of meetings with Parliamentarians equipped them with evidence on population and development. Sensitized leaders became advocates for prioritizing family planning within Provincial Assemblies as well as within their respective parliamentary committees.
Members of the Provincial Assemblies (MPA) highlighted the need for enhanced resources as well as the need to engage religious leaders on the issue of family planning. All MPAs agreed that it was the collective responsibility of all parliamentarians to work for the welfare and wellbeing of their people.

Political representatives of the various political parties gathered in Islamabad and Bhurban to produce a national multiparty consensus on the issue of population. All major political parties unanimously agreed that the future of the country depended upon healthy productive and socio economically well off citizens and that population planning was the key to achieve this objective. A joint statement was signed by more than 30 legislators.

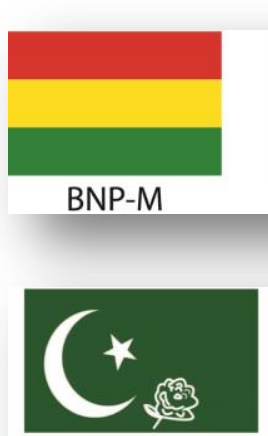

PML(F)

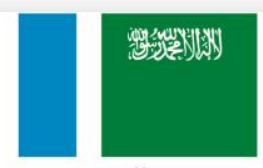

$J$

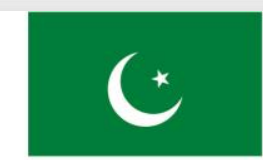

PML-Q

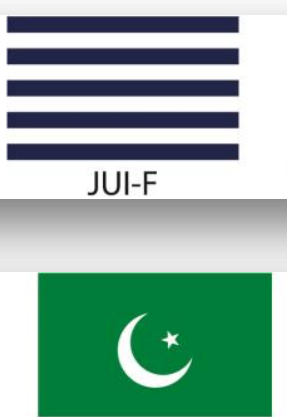

PML-N

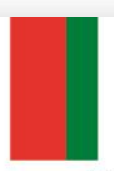

MQM

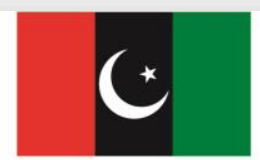

PPP

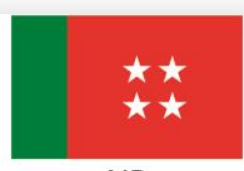

NP

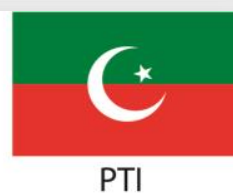




\section{A Consensus by Legislative Leaders \\ on}

\section{Population and Development}

Islamabad, September 17, 2015

We, the undersigned (Legislative Leaders, Members of the National Assembly, the Senate, and the four Provincial Assemblies representing major political parties) met at Islamabad on September 17, 2015, to discuss and build upon the consensus reached at meetings arranged by the Population Council during 2013-2015 with Federal and Provincial Legislators and to strategize the role that Legislators can play to promote family health and well-being of the people of Pakistan.

- The Constitution of Pakistan enshrines the health and well-being of all its citizens as a basic Principle of Policy (e.g. Article 38, d).

- Islam declares the preservation and sustenance of human life as an inalienable right of all individuals and families. Prominent Ulema-e-kiram and Mashaikh-e-uzzam of our country have lent their support for the fulfilment of this right. All other religions also stress the sacredness of human life and the importance of family well-being.

- Yet we have not been able so far to ensure compliance with the Constitutional obligation and the religious injunctions mainly because our rapid population growth over takes and erodes our resource-generation capacity. We have fallen far behind many other Muslim countries and other developing countries in improving the standards of health care for the vast majority of our people. For example, the deaths of 14,000 women every year in Pakistan due to pregnancy-related causes are a grave tragedy which can be prevented if suitable measures are taken. Proper care and attention also needs to be given to the upbringing and education of girl-children in particular.

- Based on the injunctions of the Holy Quran and Sharia and on values of balance articulated by other religions as well, we endorse the concept of birth-spacing. This method helps ensure that all births are planned and wanted (and is not the result of unintended pregnancies). Medical and health services need to be urgently expanded so that all pregnancies are taken care of safely, so that all deliveries of infants are conducted by skilled birth-attendants, and so that all new-born infants survive and grow in good health.

- In our individual capacities we have reached a consensus on the vital role of elected Legislatures in safeguarding the essential aspects of Population and Development. These aspects include maternal and child health care, appropriate birth-spacing, improved access to family planning services and the importance of other relevant dimensions of development.

- We offer our active support to catalyse effective and urgently required political action at all levels to help ensure the health and well-being of all families, and to achieve the ultimate goal of creating a healthy, prosperous and welfare-oriented society. 


\begin{tabular}{|c|c|}
\hline Name / Signature & Name / Signature \\
\hline Mr. Naeem Rathore & Ms Naghma Mushtaq \\
\hline Malaika Raza & Dr. Farid Ahmed Pirzada \\
\hline Tamkeen Akhtar Niazi & Nehal Hashmi Advocate \\
\hline Farhatullah Babar & Nasim Hayat \\
\hline Dr. Nausheen Hamid & Taj Haider \\
\hline Dr. Jehanzeb Jamaldini & Dr. Ashok Kumar Senator \\
\hline Mr. Arbab Jehandad Khan & Amina Sardar \\
\hline Nagina Khan & Touseef Abbasi \\
\hline Ghulam Habib & Nural Sehar Abbas \\
\hline Saleem Khan & Shaukat Ali Yousafzai \\
\hline M. Azam Swati & Brig(R) John Kenneth Williams \\
\hline Mrs. Fauzia Kasuri & Ayesha Javed \\
\hline Rahib Hammed Durrani & Dr. Shiza Massab Ali Kharal \\
\hline Qaiser Ahmed Shaikh & Nishat Ahmad Khan Daha \\
\hline
\end{tabular}



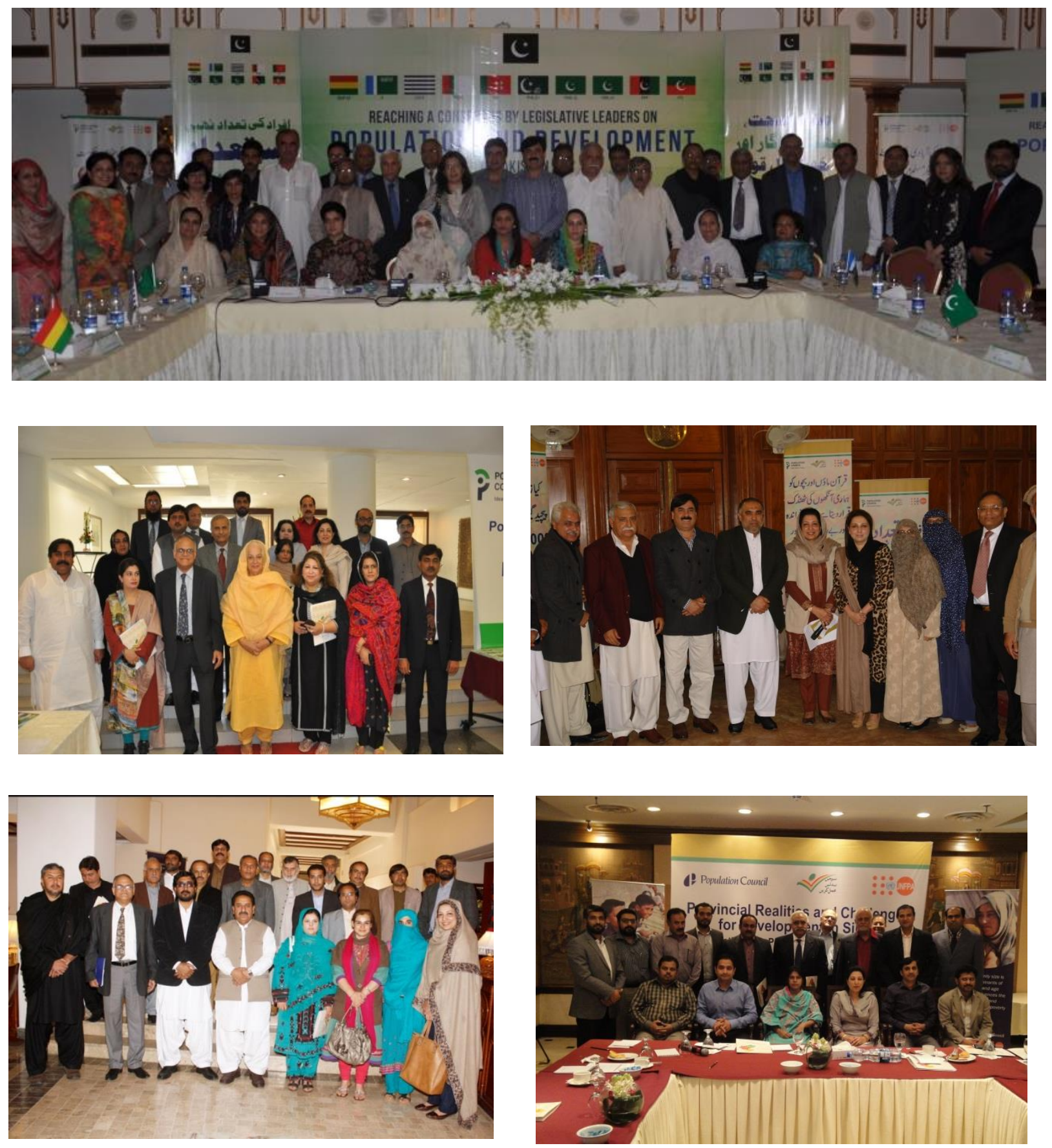

Top: Members of National Assembly and Senate; Middle left: Members of Punjab Provincial Assembly; Middle right: Members of Khyber Pakhtunkhwa Assembly; Bottom left: Members of Balochistan Provincial Assembly; Bottom left: Bottom right: Members of Sindh Provincial Assembly. 


\section{Provincial Commitments}

\section{Pakistan is committing to a new FP2020 goal of a contraceptive prevalence rate of $50 \%$ based on a composite ${ }^{1}$ of the provincial goals.}

At the July 2012 Family Planning (FP) Summit in London, Pakistan made a national commitment to raise its contraceptive prevalence rate (CPR), from the then estimated level of 35 percent, to 55 percent by 2020 . The country was waiting for the 2012-13 Demographic and Health Survey. Following the summit, the provinces of Punjab, Sindh, Khyber Pakhtunkhwa, and Balochistan made their own commitments to FP2020, ensuring that Pakistan's family planning goals rest on the firm foundation of provincial ownership and commitment, reflect provincial realities and priorities, and are the result of decisions based on recent provincial evidence. Meetings with key high level officials helped foster greater realization within the provincial governments of the importance of ensuring funds for strong family planning initiatives.

Chief Ministers and senior policymakers of finance, planning, and population welfare departments were briefed and convinced to provide additional resources to meet these ambitious goals. These senior policymakers expressed their support for prioritization of family planning in provincial strategies and budgets. The four major provinces agreed on aspirational goals and accelerated programming to "bend the current slow curve of increase" in CPR."

In September 2014, at a high-level meeting, Prioritizing Family Planning for Achieving Provincial Maternal Child Health and Development Goals, the provincial health and population welfare departments of the four major provinces-together with some federal representatives, formally announced their CPR goals for 2020.

\section{Provincial FP2020 CPR Commitments}

\begin{tabular}{llll}
\hline Punjab & $55 \%$ & KP & $42 \%$ \\
Sindh & $45 \%$ & Balochistan & $32 \%$
\end{tabular}

\footnotetext{
${ }^{1}$ The composite goal includes ICT Islamabad, FATA, Gilgit-Baltistan, Azad Jammu, and Kashmir in addition to Punjab, Sindh, KP and Balochistan. .
}
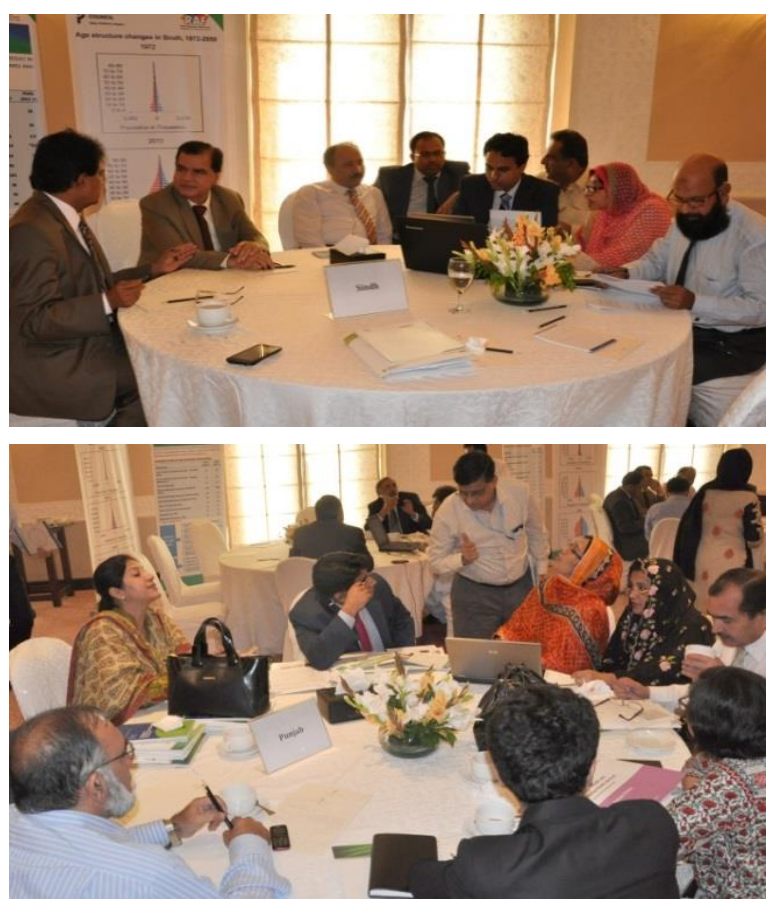
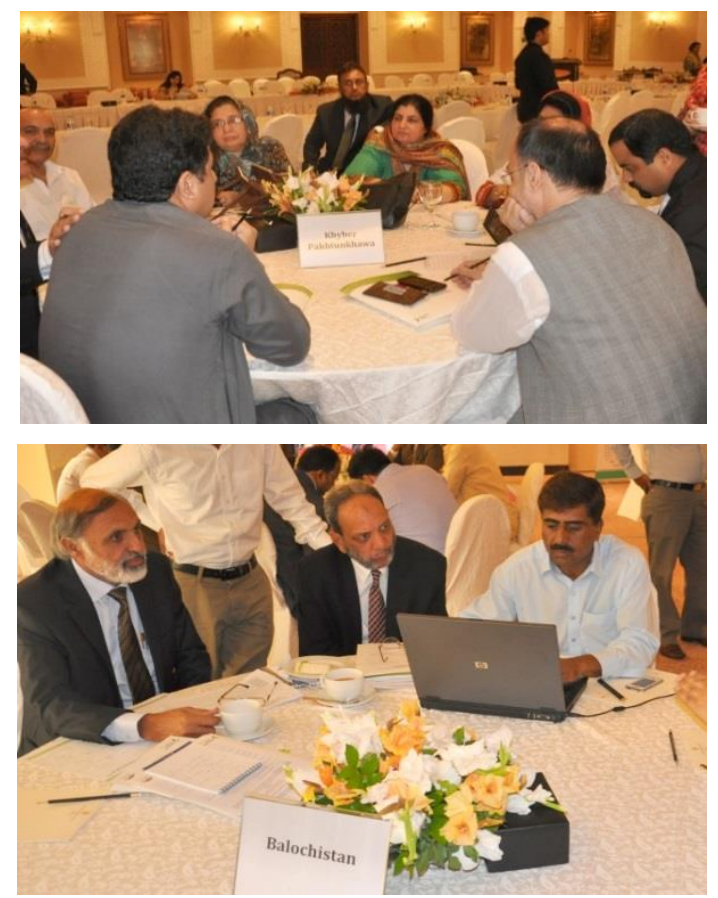

Provincial teams working on CPR goal setting.

Top left: Sindh

Top right: KP

Bottom left: Punjab Bottom right: Balochistan 
Provincial Contraceptive Prevalence Rate Goals for FP2020

\section{Punjab's CPR Commitment for 2020}

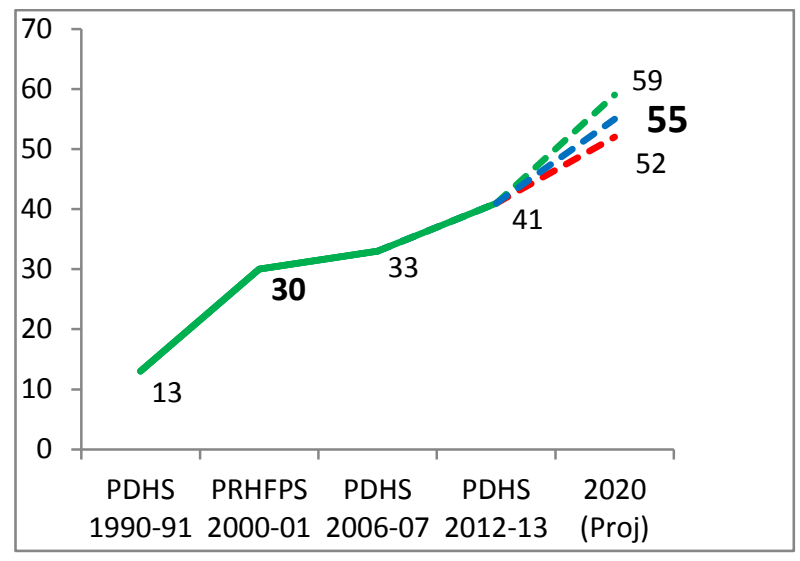

Balochistan's CPR Commitment for 2020

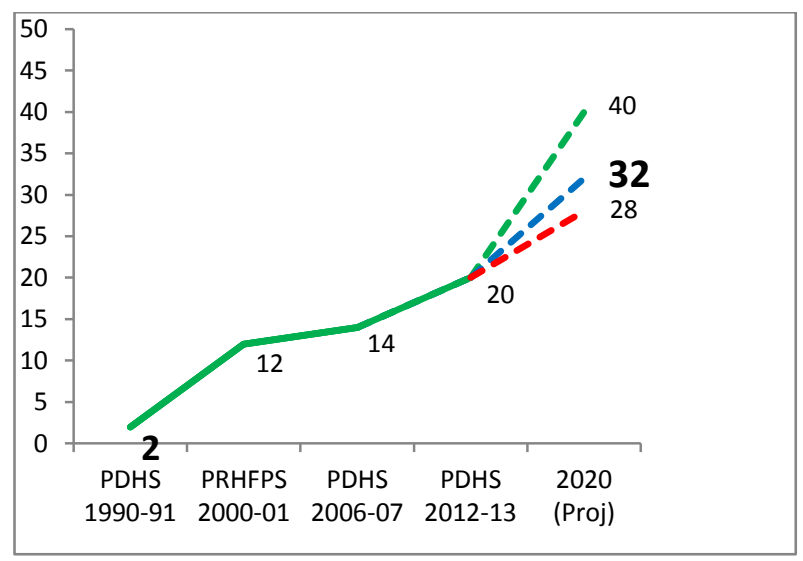

\section{Sindh's CPR Commitment for 2020}

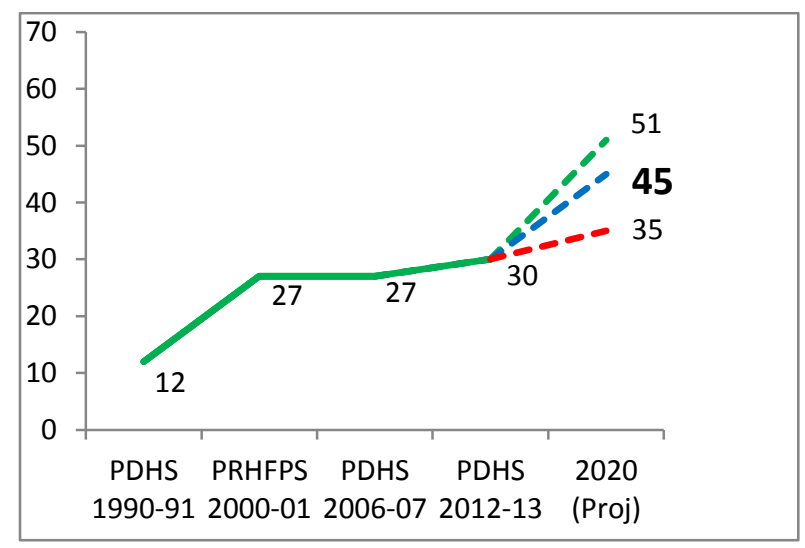

\section{KP's CPR Commitment for 2020}

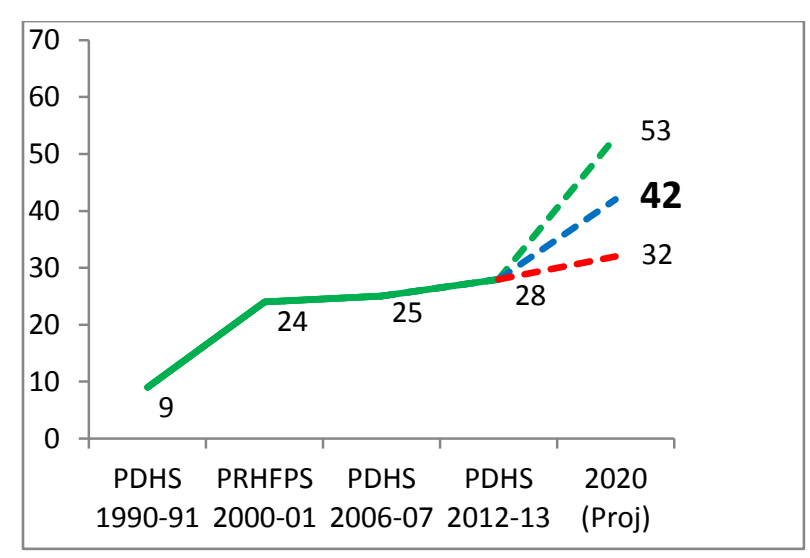

\section{Legend}


This document was produced by the Population Council Islamabad with support from the United Nations Population Fund (UNFPA).

Suggested Citation: Government of Pakistan, UNFPA and Population Council. 2015. Unveiling the Consensus: Putting People First in Pakistan's Development Agenda. Islamabad: GOP, UNFPA and the Population Council. 